\title{
Cyprus in Europe: Solving the Cyprus Problem by Europeanizing it?
}

\author{
By Peter A. Zervakis *
}

At the time of the Treaties of Rome in 1957 creating the European Economic Community (EEC), and the Agreements of Zurich and London in 1959 founding the Republic of Cyprus, both of the new "postmodern polities" emerged despite the lack of any historical precedent. ${ }^{1}$ Based on international treaties rather than domestic constitutions, they were constructed to open the traditional sovereign nation-states and their borders to trans-national modes of European governance. ${ }^{2}$ Because they were not typical state actors, they did not fit into the political landscape of the era. Given the complicated but carefully balanced institutional and power sharing arrangements between the member nations of the EEC and the supranational institutions in one case, and the divergent Greek and Turkish ethnicities of the Republic of Cyprus forcing compromises in collective decision-making in the other, these resembled neither classical sovereign nation-states nor post-war modern international organizations like the United Nations (UN), which were grounded mainly on diplomatic interactions between governmental representatives. The creation of supranational organs like the Commission, with legal competencies in particular policy areas (internal market); the directly permeating quality of European (economic) law in the member states; and the introduction of direct elections to the European Parliament since 1979, as well as the single currency in 1999/2002, all belong to the distinctive quality of the European Community (EC) as "un objet politique nonidentifié." 3

The distinguishing characteristics of the "incomplete statehood of Cyprus"4 include, first, the limit of sovereign rights for the Republic of Cyprus, based on the required consent of the guaranteeing powers (United Kingdom,

\footnotetext{
* Peter Zervakis is Senior Research Fellow at the Center for European Integration Studies, Bonn, Germany, and lecturer in Political Science at the University of Bonn; visiting professor at the University of Innsbruck, Austria, and Reader at the German Armed Forces Command and Staff College in Hamburg. He would like to thank H. Tarik O? uzlu from Bilkent University for his helpful comments in revising the paper

${ }^{1}$ Thomas Dietz, ed, The European Union and the Cyprus Conflict. Modern Conflict, Postmodern Union, (Manchester University Press, 2002), 203. [Author: publisher?]

${ }^{2}$ Peter Zervakis, "Globalisierung und Europäisierung als Herausforderungen für den Wandel des Nationalstaats in Europa," in Ethik, Politik und Kulturen im Globalisierungsprozess, Eine interdisziplinäre Zusammenführung, ed. Ralf Elm (Bochum, 2003), 295. [Author: publisher?]

${ }^{3}$ Alberta M. Sbragia, "Thinking about the European Future: The Uses of Comparison," in Europolitics, ed. Alberta M. Sbragia (Washington, D.C., 1992), 257; and Dimitris Chryssochoou, Towards a civic conception of the European polity, ESRC Working Paper 33 (University of Sussex Press, 2001), 24.

${ }^{4}$ Christopher Brewin, The European Union and Cyprus (Huntingdon, 2000), 1-3.
} 
Greece, Turkey) to any domestic constitutional changes. Second, these powers had the right to intervene, either commonly or singularly, for the restoration of state unity. Furthermore, sovereign English military bases (almost three percent of the island surface of Cyprus) provided an anachronistic feature comparable only to the four-power status of Berlin, and the power sharing between the two contrasting ethnic groups became institutionalized at the cost of the majority principle. ${ }^{5}$ Finally, from the beginning, both non-state constructs were missing the unifying concept of a national identity. Therefore, the founding documents of the EEC as well as the Cypriot Volksgruppenstaat ${ }^{6}$ (communities state) guarantee to secure peace, welfare, and stability by keeping the balance between the divergent national interests through permanent negotiations between their members. ${ }^{7}$

As the economies of Germany and France integrated step by step, the injurious nationalism that had led to two world wars began to dissolve. Following the Franco-German partnership, the pledged political parity between Bonn and Paris became the engine of further integration in Western Europe despite different population ratios and geopolitical considerations. ${ }^{8}$ From 1954-59 on Cyprus, on the other hand, the Greek Cypriots fought a bloody war for independence from the British (and their Turkish Cypriot allies) and enosis (unity) with Greece. Afterward, a complex constitutional order, with mutual checks and balances, was forced upon the majority of Greek Cypriots to secure political equality with their Turkish counterparts. This sought to prevent the outbreak of conflict for the long term between not only the Greek and Turkish Cypriots but also their respective mother countries, both of which were NATO members. However, the political goal failed, largely due to the Greek majority's disinterest in and unwillingness to accept mutual cooperation with the Turkish minority based on equal rights. Indeed, three intra-Cyprus civil wars followed in 1963-64, 1967, and 1974, all featuring the direct intervention of Greece and Turkey. ${ }^{9}$

In the past decades, the European Union has become a success story in promoting peace, stability, and welfare among its members. In spite of different size and population, its politically equal member states have learned voluntarily to handle conflicts among one another without violence and without the need for a supranational institution with its own monopoly of power. Worldwide, the

\footnotetext{
${ }_{5}^{5}$ Peter Zervakis, :Die politischen Systeme Zyperns," in Die politischen Systeme Osteuropas, ed. Wolfgang Ismayr (Opladen, 2002), 847.

${ }^{6}$ Christian Rumpf, "Verfassung und Recht," in Handbook on South Eastern Europe. Vol. VIII. Cyprus, eds. Klaus-Detlev Grothusen, Winfried Steffani, and Peter Zervakis (Göttingen, 1998), $158-60$.

${ }^{7}$ Tozun Bahcheli, "Domestic Political Development," in Handbook, eds. Grothusen, Steffani, and Zervakis, 98; and Geir Lundestad, "Empire" by Integration (Oxford, 1998), 3-4.

${ }^{8}$ Peter Zervakis and Sébastien von Gosslar, "40 Jahre Elysée-Vertrag: Hat das deutsch-französische Tandem noch eine Zukunft?” Aus Politik und Zeitgeschichte B 3-4 (2003): 6-13.

9 Peter Zervakis, “Zypern," in Studienhandbuch Östliches Europa, vol.1, ed. Harald Roth (Cologne, 1999), 442-43.
} 
EU has gained role-model status, demonstrating how peace, prosperity, and conflict prevention are possible through mutual agreement, to the benefit of all parties. After the German reunification in 1990, the EU members, as the actual "masters of the treaties," signed the Treaties of Maastricht and Amsterdam respectively, expanding their predominantly economic association incrementally into a political union. This took place through the introduction of a single currency (against the will of - not least - the Germans), reforms of the existing EU institutions, and the establishment of policy areas of further development, such as the Common Foreign and Security Policy, as well as the European Security and Defense Policy, all of which led to the so-called deepening of the Community. Above all, the EU offered to open its doors to eight aspirant countries from former communist-dominated Eastern Europe, along with Malta and Cyprus. Up to this point, the Community had been largely dominated by Western European nations. But with this political project of millennial, developmental proportions, the EU will contribute through its enlargement to the stabilization of these nascent market-economic democracies in Central and Eastern Europe by promoting massive modernization, transformation, and internal reforms. Along with the NATO enlargement, the EU will provide for the eastward expansion of the security community established after World War II, thus creating the foundation for Europe's claim to its future role as a world player in the twenty-first century. ${ }^{10}$

When the Greek Cypriots finally applied for full membership in the EU, with strong support from the Greek motherland, the Turkish Cypriots had little intention of enabling the reunification with Greece. Rather, the Greek Cypriots sought to effectively counter the security threat presented by the Turkish Army presence to their claim of being the only sovereign people on the island. With the involvement of the EU's superior economic and financial strength, especially with regard to its share in world trade and its ambition to act as a "civilian power Europe"11 (thus using preferably non-military means in order to promote democratic principles worldwide), the Greeks insisted on integrating the divided island on their terms after the conciliatory but exhaustive attempts of the UN of more than 30 years proved ineffective. ${ }^{12}$ Thus, importing the still-unresolved Cyprus dispute into the EU became their primary objective. From Brussels, on the other hand, the first application of the civilian power concept to the Mediterranean region seemed quite attractive, not least because of

\footnotetext{
${ }^{10}$ Michael Kreile, "Die Osterweiterung der Europäischen Union,” in Europa-Handbuch, ed. Werner Weidenfeld (Bonn, 1999), 802; and Institut für Friedensforschung und Sicherheitspolitik, Die europäische Sicherheitsgemeinschaft. Das Sicherheitsmodell für das 21. Jahrhundert (Bonn, 1995).

${ }^{11}$ François Duchêne, "Europe in World Peace," in Europe Tomorrow, ed. R. Mayne (London, 1972), 32-49; and Stelios Stavridis, "Failing to act like a "civilian power": the European Union's policy towards Cyprus and Turkey (1974-2000)," Studia Diplomatica 54:3 (2001): 75-102.

${ }^{12}$ Peter Zervakis, "The Accession of Cyprus to the EU: The Greek Viewpoint," in Cyprus and the European Union, New Chances for Solving an Old Conflict?, eds. Heinz-Jürgen Axt and Hansjörg Brey (Munich, 1997), 137-50.
} 
the Union's sheer economic preponderance in its relations with Cyprus and Turkey. Both are fully dependent on the Union - one of the largest aid donors in the world - in their trade and development. But those countries have also been politically and institutionally closely linked with the EU, since the association agreements with Turkey in 1963 and Cyprus in 1973, respectively. Recent provisional highlights of the Union's active involvement in the Eastern Mediterranean for "Regional Peace, Security, Stability, and Prosperity" include:

- The beginning of substantial accession negotiations between Nicosia and Brussels since spring 1998 for the adoption of the acquis communautaire, the conditions for the internal market, and the common policies (CFSP, ESDP, JHA) on the entire island.

- Realization of the Customs Union with Turkey after Greece dropped its veto.

- The long-term inclusion of Turkey in the future southern expansion of the Community as a necessary completion of the imminent eastward enlargement.

In this essay, the ins and outs of the dynamic process of European association and the EU membership of Cyprus (and Turkey subsequently) will be explored. This is to be analyzed in particular for the special case of Cyprus to find out whether the EU has gained more impact there as an actor or as a mere "framework" providing the basic conditions to transform the Cyprus dispute domestically. ${ }^{13}$ Therefore, the specific historical reasons for the unresolved ethno-political Cyprus question need to be examined, as well as the abortive politicaldiplomatic approaches under UN mediation up until now. The historical analysis of why all international arbitration attempts have as yet failed to resolve the Cyprus problem provides a foundation for the discussion of Europeanization as a successful model to be used in the long run for the resolution of conflicting domestic ethnic interests. ${ }^{14}$ Furthermore, this article will attempt to determine the contribution of the EU to the mutual approach of both strictly separated Greek and Turkish Cypriots through civil society institutions like the many nongovernmental organizations that are presently blossoming in Northern Cyprus and are organizing mass protests against its elected government to resume negotiations to reunify. ${ }^{15}$ Finally, the question will be addressed regarding what potential exists for the solution of the ongoing Cyprus problem under the com-

${ }^{13}$ Thomas Diez, "Why the EU can nonetheless be good for Cyprus," Journal of Ethnopolitics and Minority Issues in Europe (JEMIE) 2 (2002): 14.

${ }^{14}$ See Ralf Zoll, ed, Ein Modell zur Vermittlung konfliktärer Interessen. Die griechisch-türkischen Beziehungen und der Zypern-Konflikt (Münster, 2000); and Patrick R. Hugg, "Cyprus advances towards Europe: Realism and rationalism," Perceptions 6:3 (2001): 94.

${ }^{15}$ Nicole Schulze, "'Cracks in the Wall': Bikommunale Aktivitäten und friedensstiftende Maßnahmen auf Zypern," in Zypern. Gesellschaftliche Öffnung, europäische Integration, Globalisierung, eds. Gisela Welz and Petra IIyes (Frankfurt am Main, 2001), 23-43. 
mon umbrella of the UN and the enlarging and constitutionally deepening EU, given the current easing of tensions between both ethnic groups on the island, as well as between the mother countries, Greece and Turkey. One has finally to take into consideration that the latter in the meantime is seriously trying to implement domestically the Union's high democratic standards in order to qualify for EU membership, but still resists any change to the status quo on the island of Cyprus. ${ }^{16}$

\section{The History of the Cyprus Problem}

The Cyprus problem embodies an unresolved nationality conflict between two ethnic groups indigenous to the island. The issue is one of the last remnants of the century-old fate of the declining Ottoman Empire, indeed one of the most complicated problems in modern European history. ${ }^{17}$ With the empire's decline, the relatively liberal position of the British colonial administration, which took over Cyprus in 1878 from the Ottomans, was confronted with both the penetration of Greek nationalism (enosis, or unification), and later the TurkishKemalistic reactive movement of taksim (separation). Resulting from concessions for extensive administrative autonomy, especially in education, a strict separation of both religious groups favored the cultural inclination of each group toward their respective motherland. An independent, inclusive, co-determining nationality could not develop under these conditions. Thus, the Greek Cypriot revolt against the British rule, with demands for annexation to Greece, resembled more the irredentist movements in South Eastern Europe than the Third World anti-colonial independence movements. The "consociational"18 democracy as founded in the Constitution of the Republic of Cyprus (since 1960), with its extensive self-administration for both ethnic groups, proportional ethnic representation in the government branches, and comprehensive veto powers for the Turkish Cypriot Community, was therefore not conducive to the amicable solution of the Cyprus issue because there was no common consensual political culture. ${ }^{19}$ At the end of 1963, the powder keg exploded: Archbishop Makarios III, as president of the Republic, unilaterally demanded from the Turkish Cypriots the revision of the constitution, meaning a loss of many of their guaranteed rights. Their anticipated rejection heightened tensions between the various armed radicals, so that a very small provocation from the Greeks

\footnotetext{
${ }^{16}$ See the latest Report of the EU Commission, Continuing Enlargement. Strategy Paper and Report of the European Commission on the progress towards accession by Bulgaria, Romania and Turkey (Brussels, 2003), 15-16, at http://europa.eu.int/comm/enlargement/report_2002/pdf/strategy paper2003 full en.pdf (last access: 10 November 2003).

${ }^{17}$ Peter Zervakis, "Historische Grundlagen," 69-90.

${ }^{18}$ Albert F. Reiterer, Cyprus. Case study about a failure of ethno-national understanding (Frankfurt am Main, 2003), 129.

${ }^{19}$ Zervakis, "Die politischen Systeme Zyperns," 847-51, 880.
} 
sufficed to trigger the spiral of violence in Nicosia, which received additional momentum from several interventions from Greece and Turkey. The civil war of 1963-64 resulted in the division of Nicosia and the solidification of the Turkish enclave.

The Cyprus issue became internationalized on several occasions, particularly with the UN Security Council Resolution to deploy UNFICYP (United Nations Peace-keeping Force in Cyprus) for the prevention of further clashes, the restoration of public order, and the return to normality. In the meantime, the blue helmet deployment, originally planned for three months, continues today, having developed into the world organization's longest peacekeeping mission and international diplomatic fiasco. Both local conflicting parties have yet to succeed at finding a path to peaceful conflict management despite the help of the UN and endless peace talks between the political representatives of both communities. Moreover, the Turkish army's invasion in 1974 was caused by the Greek coup against President Makarios, which was supported from the Athens Junta and called for incorporation of Cyprus into Greece. Consequently, a "population exchange" and the forced military division of the island territory followed under the auspices of the UN. Thus, the end of the intra-Cyprus warfare was enforced by the Turkish intervention and the bold deployment of the UNFICYP-soldiers, who have watched over the ceasefire line since 1964. But this did not suffice for an enduring peace on Cyprus. Despite the noble intentions of all UN Secretaries General since the 1960 s to overcome the island's division peacefully, the representatives of both ethnic groups have consistently proven themselves unwilling to reach a durable compromise, as the models for possible solutions offered by the conflicting parties diverge ever more from one another. On the one hand, the Greek side has sought a reunification, namely based on the status quo ante in the form of a federation with strong, predominantly Greek central power. On the other hand, the Turkish minority's determination for separation has strengthened continually since 1964, materializing in their unilateral declaration of independence on 15 November 1983, which Turkey alone recognizes.

Another hindrance to a solution among the insular groups lies in the difficulty for involved regional (Greek and Turkish) and international (UN/EU/U.S.) actors to persuade the Cypriots to change the status quo, which has historical roots but also provides rather stable conditions. A survey in the Republic of Cyprus in March 1990 confirmed the increasing mutual alienation due to the sweeping absence of social, cultural, and economic contacts between the ethnic groups for almost thirty years. The majority of the surveyed Greek Cypriots want to keep the Turkish Cypriots at a distance, and categorically reject closer familiar or good-neighborly relations. ${ }^{20}$ The Turks on the island's northern part, conversely, display sympathy for a closer relationship with the

${ }^{20}$ Nathalie Tocci, The 'Cyprus Question': Reshaping Community Identities and Elite Interests Within a Wider European Framework, Working Document 152 (Brussels, 2000), 9. 
EU for economic reasons. Their historically legitimate distrust of looming Greek dominance leads them to insist on independence, as well as the prior accession of Turkey to EU membership. ${ }^{21}$ A simple solution to the Cyprus issue based on either reunification due to a postulated, insular identity (common colonial past, customs, norms, and practices) or the peaceful co-existence of both communities in one political entity (the official Greek view) or, on the contrary, sticking to the status quo (Turkish view) can be thus ruled out in the short term. But today, with the introduction of the European perspective, the Cyprus problem definitely no longer has the same meaning as it did in 1960, 1964, or 1974, despite the everlasting diplomatic negotiations on reunification, which continue as if the issue has not changed over the last forty years.

\section{The Internationalization of the Cyprus Problem}

In March 1964, the "dummy government" of President Makarios was officially recognized by the General Assembly and the Security Council of the UN (Res. 186/1964) as the sole internationally legitimate body for the entire republic. Since then, the Greek Cypriot politicians have been able to play out their claim of being the sole representation of the island - in affront to the island's Turks to their diplomatic and economic advantage. After the island divided in 1974, the Greek southern part of the island accomplished a "small economic miracle"22 through massive financial support from international organizations, tourism, and offshore activities. Regarding the political quest to overcome the island's division, the Republic of Cyprus, with Greece's support, sought the assistance of the UN. Thanks in part to the efforts of the UN Secretaries General, several agreements were completed in 1977 and 1979 between the leaders of both Cypriot communities, Makarios (and after his death Spyros Kyprianou) and Rauf Denktash. ${ }^{23}$ These contained for the first time basic directives for future negotiations: ${ }^{24}$

- Formation of a bi-communal Federal Republic consisting of two parts and both ethnic groups. Each group should have the rights of its own territory, but the central government would have the core responsibility for guaranteeing national unity.

- Successive demilitarization of Cyprus and the insurance of independence, sovereignty, territorial integrity, and non-aligned status of the republic against integration or secession of either section of the island.

- Beginning of negotiations on the restoration of freedom of movement, free choice of residence, and compensation for property titles from displaced persons.

\footnotetext{
${ }^{21}$ Dietz, European Union, 157-58.

22 See Demetrios Christodoulou, Inside the Cyprus Miracle (Minneapolis, 1992).

${ }^{23}$ For a critical assessment of Denkta?'s ambivalent role in the Cyprus dispute, see Michael Knüppel, Rauf R. Denkta? und seine Rolle im Zypernkonflikt (Göttingen, 1999).

${ }^{24}$ Paris Varvaroussis, Deutschland und die Zypernfrage (Munich, 1995), 249-51.
} 
- Initiating confidence-building measures to build trust between both communities.

Although the Security Council and the General Assembly commended these principles as a breakthrough in the Cyprus negotiation process and bolstered them in a few resolutions, approval of a comprehensive accord failed among both ethnic groups. One cause stems from the diametrically opposed understanding of the term "federalism" between the Greeks and Turks in Cyprus. While Greek Cypriots see a central government with the ultimate responsibility of securing the so-called three freedoms (freedom of movement, property, residence) on the entire island, Turkish Cypriots aspire to found two partial states, each with their own sovereignty rights, tied to a loose confederation. ${ }^{25}$ The Greek Cypriots equate the admission of an independent Turkish Cypriot sovereignty with the solidification of the island's division since 1974; thus they categorically reject a confederative concept for the island. ${ }^{26}$

On the initiative of UN Secretary General Perez de Cuellar, who conceived two further schemes for a resolution in 1983, a rapprochement was once again in sight. But this time, the proposals failed, not because of Rauf Denktash, who considered the arrangement worth signing, but rather because of the Greek side, which feared that it had diverged too far from its own ideas.

The catalogue of suggestions presented by Boutros Boutros-Ghali in 1992 is the most comprehensive proposal on the Cyprus issue to date. In detail, the future coexistence of both groups is managed concretely in the proposal. The Security Council adopted Boutros-Ghali's "Set of Ideas" enthusiastically in two resolutions (No. 774/1992 and No. 789/1992) as the basis for the attainment of a settlement. This time, the Greek Cypriots accepted essentially all 100 points, while the Turks agreed to 91 . Nevertheless, the former signaled the decisive misgiving: Denktash demanded a weak central government with strong, partial sovereignty in the sub-states and representative parity in the council of ministers, while advocating a restrictive course regarding the open issue of the return of refugees (he rejected a Turkish Cypriot resettlement and the surrendering of useable agricultural land in his constituency). He also stipulated effective rules for the protection of his ethnic group as conditions for demilitarization. In order to oblige Denktash and achieve the rapprochement of both Cypriot groups, Boutros-Ghali introduced a package of confidence building measures (among others, opening of the Green Line for border transport, intensification of encounters between members of both societies, youth and student exchanges, and language classes) to both negotiation leaders. ${ }^{27}$ Above all, the Turkish

\footnotetext{
${ }^{25}$ Nanette Neuwahl, Cyprus, Which Way? - In Pursuit of a Confederal Solution in Europe, Jean Monnet Working Paper 4 (Boston, 2000), 9.

${ }^{26}$ Bahcheli, "Domestic," 117.

${ }^{27}$ Maria Hadjipavlou-Trigeorgis, "Little Confidence in Confidence Building? Conflict Resolution in the Context of the United Nations," in Cyprus, eds. Axt and Brey, 36-54.
} 
Cypriots were favored by this package of measures, because it would have contributed to the lessening of their diplomatic and economic isolation and stimulated growth in its GNP of up to 20 percent. ${ }^{28}$ Nevertheless, the Turkish Cypriot leadership rejected the agreement in April 1994.

Subsequently, the relationship between the acrimonious parties worsened dramatically, and reached a new all-time low in 1997/98. In addition, the Greek Cypriot policy toward Europe, with its strengthened cooperation against the resistance of the TRNC, was largely responsible for this. During this stalemate, the U.S. Delegate to Cyprus, Richard Holbrooke, presented his new plan in November of $1997 .{ }^{29}$ Along the cease-fire line, the creation of a third, mixedpopulation zone was to be created and later be given back to the Greek Cypriots. There the Turkish Cypriots, along with Greek Cypriots who had been displaced from that area, would be allowed to work and live together with the protection of multinational troops under U.S. leadership. The provisional government would prepare for the construction of a federal Cypriot Republic as well as the accession of Cyprus to the EU, but with Turkish participation.

However, the Turks rejected this proposal as well (after initial assent), because the Luxembourg EU-summit in December snubbed Turkey's hopes to qualify as candidate for membership. The Greek Cypriot government had to realize that the TRNC and Turkey showed no interest in solving the Cyprus issue on UN terms, and both sides had grown more distant from the other than was the case at the outbreak of the conflict. Other political options were being explored by the Greek Cypriots.

\section{Europeanizing the Cyprus Problem}

\section{The Republic of Cyprus Approaches the Community}

After the internationalization of the Cyprus issue, with the fruitless attempts at peace arbitration from five UN Secretaries General failed and the political weakness of that international organization was revealed, the liberal President Georgios Vasileiou gave in to the pressure from the Greek government of Andreas Papandreou and submitted in the name of all Cyprus an application for full membership in the EC on 3 July 1990. The step relied considerably on the Association Agreement from 1973, which built an official tie between the EC and the Republic of Cyprus securing the openness of the traditional British market for Cypriot products; the agreement further planned for the creation of a customs union in two stages within two years. The accord also contained numerous agreements for the removal of all trade and customs barriers between both partners, with the help of the adoption of a common customs tariff, the harmonization of several policy areas (competition, national subsidies, legal and

\footnotetext{
${ }^{28}$ Martin Pabst, "Zypern: UN, EU und der Status quo," Vereinte Nationen 49:4 (2001): 141.

${ }^{29}$ Jürgen Reuter, "Zypern, Vereinte Nationen und Europäische Union," KAS/Auslandsinformationen 9 (2001): $28-30$.
} 
administrative convergence), and the guarantee of free movement of goods, such as agricultural products, through the Republic. In addition, the agreement included the provision to form a common Association Council. After extending the first stage several times due to incalculable obstacles regarding the island's division, a modus operandi concerning the second stage was reached, according to which the customs union would be realized completely in two phases by 2002. ${ }^{30}$ Between 1977 and 1994, Cyprus received a total of 136 million ECUs from the Community in form of loans, non-repayable assistance, and special payments. With the exception of a certain proportion reserved specifically for the Turkish Cypriot population, many projects were financed with those resources for the improvement of infrastructure in the capital city of Nicosia (city planning and development, waste disposal, and electricity). In this fashion, all island inhabitants reaped benefits. ${ }^{31}$

When the Greek Cypriot decision-makers were no longer satisfied merely with the customs union near the end of the 1980s, they began to strive for full membership, but were nevertheless motivated in this direction less by economics than by politics. They hoped that the prospect of membership in the EU could give a new impetus to the resolution of the Cyprus problem. At the very least, they wanted to bring in the Community to finally take over responsibility for the local conciliation of the conflict. This would also provide a minimal guarantee of security for the Greek Cypriots from the Turkish army. ${ }^{32}$ Nevertheless, Vasileiou hesitated to carry out this change in policy, because he feared that the Europeanization of the Cyprus issue would unnecessarily burden any future agreement with the Turkish Cypriots under UN intervention. Furthermore, Evropi enjoyed little respect among the unions and the largest parliamentary party, the communist AKEL, because people feared the disappearance of their own small and highly subsidized industries and remembered the lukewarm support from the Community at the time of the Turkish invasion in the summer of 1974. Therefore, the Greek Cypriots' turn towards Europe can be seen as a tactical move to neutralize the Turkish military occupation, which was seen as a threat to the Greek Cypriot claim to exclusive rule. Moreover, Greece had belonged to the EC as tenth member state since 1981, while Turkey was not a member. In addition, all Athens governments up to 1999 tried adamantly to convince their EU partners that Turkey could not claim to belong to Europe because of the Cyprus ordeal, nor should their adversary be regarded a part of the Community's Mediterranean interests. ${ }^{33}$ (Only three years later, the EU

\footnotetext{
${ }^{30}$ Commission of the European Communities, Regelmäßiger Bericht 1998 der Kommission über Zyperns Fortschritte auf dem Weg zum Beitritt (Brussels, 1998), 6-7.

${ }^{31}$ Commission of the European Communities, Stellungnahme der Kommission zu dem Beitrittsantrag der Republik Zypern (Brussels, 1993), 15.

${ }^{32}$ Neill Nugent, "EU Enlargement and the 'Cyprus Problem'," Journal of Common Market Studies 38:1 (2000): 136

${ }^{33}$ Zervakis, "Accession of Cyprus," 142.
} 
Commission supported the petition from the Greek Cypriots - which largely came about due to pressure from Greece. ${ }^{34}$ ) However, the Commission emphasized the economic inequality between both parts of the island, and stressed that the integration of Cyprus into the Community would first require a peaceful, balanced, and enduring resolution of the Cyprus issues. ${ }^{35}$ It also assured the UN Secretary General of the Community's support of his efforts in the political settlement of the Cyprus question.

In this last point, the problematic nature of the accession application for the Turkish parties as well as the (West) European member-states becomes clear. The Turkish leadership and Turkey objected vehemently to the unilateral Greek Cypriot application for EU membership in the name of the entire island. They justified their arguments with the international treaties of 1959-60, which excluded Cyprus from entrance into any international organization to which both Greece and Turkey did not belong. ${ }^{36}$ Thus they rejected categorically any EU accession for the island if the open question of Cyprus's status were not addressed; otherwise, they threatened the incorporation of the TRNC into Turkey if the EU took in the Greek-dominated Republic. In addition, the Turks perceived a connection between the entrance of Cyprus into the EU and the integration of the island with Greece, which relates to the old énosis movement, "only by other means." 37 The leadership of the TRNC did not relent from its main political demands, even in the face of potential economic benefits for the population. Since then, it has rejected participation in the Cypriot negotiating delegation, because that would mean an affirmation of the Greek Cypriot claim to exclusive representation, and due to majority relations it could not build its own negotiating position vis-à-vis the EU.

Another reason for the three-year delay for an EU position on the Greek Cypriot accession application has to do with the EU partner states' minimal interest in membership of a divided Cyprus, especially compared to its activity with the Eastern European enlargement. ${ }^{38}$ In the case of the accession of a divided Cyprus into the Community, 15 governments, 16 parliaments, and all important institutions of the EU, including the European Investment Bank and the European Central Bank, all have a say in the matter. Given the seemingly insuperable difficulties, even into the 1990s neither the heads of states in the Council nor the Commission showed any interest in a direct or indirect conflict arbitration role in a distant, problematic, peripheral region. ${ }^{39}$ Instead, the Community limited itself unobtrusively to supporting all pertinent UN resolutions.

\footnotetext{
${ }^{34}$ Commission, Stellungnahme, 22.

${ }^{35}$ Commission, Stellungnahme, 23.

${ }^{36}$ See Maurice H. Mendelson, Why Cyprus Entry into the European Union Would be Illegal. Legal opinion, Meto Print, London, 2001.

${ }^{37}$ Tozun Bahcheli and Nicholas X. Rizopoulos, "Beyond Partition," War Report 54 (1997): 18.

${ }^{38}$ Commission, Stellungnahme, 23, 43, 64; and Brewin, European Union, 3-14.

${ }^{39}$ Nugent, "EU Enlargement," 138-39.
} 


\section{Accession Negotiations as a Catalyst for a Solution?}

With the positive response to the Greek Cypriot accession application, the European Union became directly involved in the insular conflict for the first time. At the beginning of October 1993, the EU Council of Ministers assigned the Commission to conduct preparatory talks with the Republic of Cyprus, in order to familiarize them better with the acquis communautaire. The peculiarity of the Cyprus application became evident once again at the EU summit in Corfu in June 1994. On the initiative of the Greek EU presidency, who threatened its partners otherwise that it would not ratify the accession of Austria, Sweden, and Finland, it was decided to include Cyprus and Malta in the group of Central and Eastern European candidate countries.

Eventually, through a historical compromise, the French president succeeded for the first time on 6 March 1995 at finding an actual date for the beginning of accession negotiations with the Greek government of the Republic of Cyprus without making such talks dependent on the condition of a previous agreement with the Turkish Cypriots. In 1999, a Fourth Financial Report was signed with Cyprus for 72 million ECUs for the structural preparation of the Republic's accession (i.e., development of civil society and promotion of projects in the interest of both ethnic groups); 54 million Euros will be given for the period 2000-2004. ${ }^{40}$ Consequently, Athens, despite hefty domestic resistance, promised to lift its veto against the establishment of a customs union with Turkey and ceased to boycott the enlargement process. At the end of 1997, the European Council of Luxembourg decided to implement a special convergence strategy with Cyprus and opened a lucrative Community economic adaptation program with the Turkish Cypriot population; at the same time, however, the EU rejected Turkey's application for membership brusquely. On 30-31 March 1998, formal negotiations over the "conditions of accession to the Union and the corresponding adjustment to the Treaties" began with Hungary, Poland, Czech Republic, Estonia, Slovenia, and Cyprus. ${ }^{41}$

However, none of the Turkish Cypriot representatives participated in the actual accession preparations, such as evaluation or screening, intensified convergence strategies, or accession partnerships, because of the political leadership's "negative position." ${ }^{42}$ The former had already closed an association agreement with Turkey in August, which prefaced a partial integration of both partners in certain policy areas. ${ }^{43}$ Still, the Community exacerbated the intra-Cypriot conflict with their Hellenophile decision, because they refused, like its stubborn member in the Balkans, to treat the Turkish Cypriots as equal partners, which under the circumstances could have been possible without acknowledging the TRNC.

\footnotetext{
${ }^{40}$ Commission of the European Communities, Regelmäßiger Bericht 1998 der Kommission über Zyperns Fortschritte auf dem Weg zum Beitritt (Brussels, 1998), 8.

${ }^{41}$ Commission, Regelmäßiger Bericht 1998, 5.

${ }^{42}$ Commission, Regelmäßiger Bericht 1998, 8.

43 Pabst, "Zypern," 142.
} 
Only after receiving some pressure from the Commission did the Greek Cypriot government finally allow a few Turkish Cypriot representatives into the delegation (who, in any event, could have been outvoted in most key issues). Out of these suspicions, and in order to demonstrate his own independence, the Turkish Cypriot leader demanded his own negotiating delegation and separate referenda for the EU accession process, as UN Secretary General Boutros-Ghali had prescribed in 1992. In contrast, the EU maintained its negotiations with the Greek Cypriots with the vague hope that the economic and security-political advantages of EU membership for the whole island would benefit both ethnic groups. Accordingly, the Greeks, in accordance with the Commission, persisted in claiming that the prospect of EU membership would function as a "catalyst" for conflict resolution. ${ }^{44}$

At the Helsinki summit of December 1999, the European Council took its most far-reaching steps, given the "thaw" in Greco-Turkish relations: it recognized Turkey as an accession-willing future candidate for membership. However, this entailed certain political stipulations (respect for human rights, protection of minorities, democratization, rule of law, institutional stability), as the European Council had determined in Copenhagen in 1993 for all candidate countries. In response, the leaders of the EU member states emphasized that a political solution would ease the Republic of Cyprus' accession to the EU. If there were no solution by the end of the accession negotiations, the Council would then make a decision on the accession without using the political solution as a prerequisite, considering all significant factors. ${ }^{45}$

The Helsinki resolutions were depicted as a "masterpiece of Byzantine diplomacy." 46 While the tangible advantages of détente policy on the European level were demonstrated to Athens, the long-refused status of EU candidacy was granted to Turkey after Greece's assent. The EU membership negotiations with the Greek Cypriots, on the other hand, closed successfully by the end of 2002, independent of a political solution of the conflict. Finally, at the last Copenhagen Summit of 12-13 December 2002, the EU Council concluded unanimously that Cyprus (no longer the "Republic of Cyprus," as it used to be cited formally in all EU documents before) $)^{47}$ was formally accepted to become

\footnotetext{
${ }^{44}$ Commission of the European Communities, Regelmäßiger Bericht 2000 der Kommission über Zyperns Fortschritte auf dem Weg zum Beitritt, (Brussels, 2000), 10; Heinz-Jürgen Axt, “Enttäuschte Hoffnungen auf Zypern,” Europäische Rundschau 29:2 (2001): 77; Patrick R. Hugg, "Cyprus in Europe: Seizing the Momentum of Nice," Vanderbilt Journal of Transnational Law 34:5 (2001): 1360; Joseph S. Joseph, "Cyprus: From Past of Ethno-Political Division to a Future of Euro-Unity?" in Transformationserfahrungen. Zur Entwicklung der politischen Kultur in den EU-Kandidatenländern, ed. Gábor Erdödy (Baden-Baden, 2003), 230. For a critical evaluation on the assumption of a "catalytic effect," see Dietz, "Why the EU," 3-6.

45 SN 300/99, 3.

${ }^{46}$ Peter Zervakis, "Griechenland," in Jahrbuch der Europäischen Integration 1999/2000, eds. Werner Weidenfeld, and Wolfgang Wessels (Bonn, 2000), 338.

${ }^{47}$ Heinz-Jürgen Axt, "Gordischer Knoten in Kopenhagen nicht durchschlagen: Zypern, die Türkei und die EU," Integration 26:1 (2003), 77, footnote 27.
} 
an EU member by May 2004, after ratification of the accession treaties by all prospective and current member states and the EU Parliament. At the same time, Turkey was given a so-called rendezvous clause: by December 2004, the Union will definitely decide whether Turkey then meets all political criteria to start access negotiations "without any further delay." 48 Nevertheless, the reservations of some EU members concerning the accession of a divided Cyprus remain, and the EU has not bound itself legally to solve the problem while it continues to favor the accession of a reunited island:

EU membership, following a political settlement, will provide an effective framework for guaranteeing fundamental democratic and human rights and for raising living standards and reducing disparities in income. Participation in EU programmes and networks and specific EU policies to promote structural adjustment will underpin economic development in the north. ${ }^{49}$

Yet the Community has some leverage to bring the two groups into further negotiations, because only a mutually agreeable accession can elicit an easing or resolution of the conflict; however, this will require a special accord. Therefore, a few high-ranking representatives of the Commission and the Council visited the island frequently in 2002-3 to explain the complex EU position. ${ }^{50}$ There the Europeans promised to accommodate the terms of a comprehensive settlement in the Treaty of Accession until May 2004 at the latest:

$\ldots$ in line with the principles on which the European Union is founded; as a Member State (which is free to determine its own constitutional arrangements!) Cyprus would need to speak with a single voice and ensure proper application of EU law. The EU would make a substantial financial contribution to support the development of the northern part of a reunited island..$^{51}$

And Brussels continues to promote bi-communal projects like conflict resolution workshops, etc., normally organized in the buffer zone or abroad, mainly in cooperation with the UN. For the last two decades, mainly upper-middleclass professionals and academics from both sides (more or less fluent in English, the common medium of understanding in those meetings) have tried to build a climate of mutual trust and understanding among Cypriots of both eth-

\footnotetext{
${ }^{48} \mathrm{See}$ http://europa.eu.int/council/off/conclu/index.htm (last access: 10 November 2003).

${ }^{49}$ Commission of the European Communities, 2002 regular report on Cyprus's progress towards accession (Brussels, 2002), 29.

${ }^{50}$ Oliver Bauer, "Die Zypernpolitik der Europäischen Union. Interessen, Akteure und Szenarien," Perspektiven im Zypernkonflikt, eds. Abraham Ashkenasi and Georgia Duprés (Frankfurt am Main, 2002), 244.

${ }^{51}$ Commission, 2002 regular report, 26.
} 
nicities, with the aim of gradually developing a common Cypriot identity which might prove a necessary condition for the solution of the Cyprus problem. ${ }^{52} \mathrm{But}$ the participants from both communities have often met with public resistance from their own nationalist media and politicians accusing them of being unpatriotic and even treacherous. This can be seen as a clear sign for the uncompromising political leaders who keep the Cyprus dispute alive for their own internal use to preserve their traditional power over both weak societies with the help of the two competing ethnic nationalisms on the island, in the process stunting the growth of the as-yet underdeveloped Cypriot civil societies. ${ }^{53}$

Therefore, without external pressures for internal reforms - mainly as the result of the upcoming accession of the island into the EU - there is little hope that the well-established grip of the politicians on their respective civil societies will loosen. Thus prevailing nationalistic attitudes in both ethnic camps prevent the creation of a trustful atmosphere, which is a precondition for a mutual resolution of the Cyprus problem and the future function of the two communities' coexistence in a bi-communal state. Otherwise, some unresolved questions remain, with the sole factual (if not judicial) EU membership of the Greek part of the island: How can Cyprus enter the EU without officially recognizing the Turkish occupation of the island's northern part? Will the membership of just one group of Cypriots not further deepen the division of the island? In the meanwhile, has the original UN approach to accept only the Greek Cypriots' official status as representatives of the whole island (which was followed stubbornly by Greece and the EU) not proven counterproductive, while bringing them together to the negotiation table as if they were equals? And - as Günter Verheugen, the EU-enlargement Commissioner recently put it in the European Parliament - how can the ongoing deployment of UN peacekeeping soldiers be tolerated in an EU member state?

\section{Domestic Rapprochement in the Framework of the EU?}

After the progress report from the EU on 13 November 2001, the Union declared its goal in Cyprus "to find a political solution under the auspices of the UN before Cyprus enters the EU, although this does not represent any prereq-

\footnotetext{
${ }^{52}$ See Sonja Bienert, "Konflikt und Kommunikation. Peacebuilding-Aktivitäten der bikommunalen Gruppen auf Zypern," in Perspektiven, eds. Ashkenasi and Duprés, 301-49; Oliver Wolleh, "Zypern: Gesellschaftliches Rapprochement im Spannungsfeld von impliziter Anerkennung und Repression," Südosteuropa Mitteilungen 42:2 (2002): 83-99; and Culture in Common - Living Cultures in the Cypriot Communities. Proceedings of German-Cypriot Forum Conference 22-24 May 2003 Berlin/Üdersee.

${ }^{53}$ Although it seems that there is a certain asymmetrical relationship in the two civil societies with respet to the strength of active NGOs. See Caesar V. Mavratsas, Ethniki omopsychia kai politiki omofonía. I atrofia tis ellinokypriakís koinonías ton politón stis aparchés tou 21 ou aióna (National unanimity and political consensus. The atrophy of Greek Cypriot civil society at the dawn of the 21st century) (Athens, 2003).
} 
uisite for the accession." ${ }^{{ }_{54}} \mathrm{EU}$ accession and $\mathrm{UN}$ conflict resolution negotiations between both ethnic groups thus were treated complementarily, with the intention of adjusting all deviations from community law to the final accession treaty. The EU does not view itself as an active conflict arbitrator - thus it has never developed its own strategy to solve the Cyprus problem, and since 1993 it has regularly sent special envoys to simply observe the UN peace talks - but it views the accession dynamics as an opportunity that can be used to bring about an agreement. However, a failure would intensify the division on the island, to the disadvantage of both communities (who would achieve no regulation of territorial, refugee, and compensation issues, elimination of the differences in wealth, or recognition of past failures), and their motherlands (who would potentially lose both bilateral balance and Turkish EU accession) as consequences..$^{55}$

When the EU summit in Helsinki in December 1999 named Turkey a future accession aspirant, a solution to the Cyprus issue was nearly reached the following year, given the new, indirect rounds of the so-called proximity talks in Geneva and New York between representatives of the two ethnic groups and the UN's special mediator Alvaro de Soto. There he presented concrete, detailed discussion proposals for the central topics of the distribution of powers between both ethnic groups in a Cypriot "common state" and in the "component states." ${ }^{56}$ In autumn of 2000, comments from UN Secretary General Kofi Annan proved to be of particular significance for the negotiation process as well as future conflict solution. He called for the recognition of the political equal rights of both ethnic groups in order to reach a comprehensive balance between the claim to an exclusive right of representation in the Republic of Cyprus and the claim to sovereignty in the Turkish Republic of Northern Cyprus. ${ }^{57}$ Nevertheless, the Turkish Cypriots rejected Annan's suggestions, and their leadership refused further participation in the UN talks. In contrast, the EU Nice Summit greeted Annan's efforts and supported them strongly. The Union criticized the negative position of the Turkish Cypriot leader, and turned to Turkey as a means of leverage by making their progress in the EU accession process dependent on Turkey's position on the Cyprus issue..$^{58}$

In analyzing Annan's proposals, which later became the framework for his overall master plan in November 2002, it is apparent that no resettlement of the immigrated Turkish settlers was to take place, nor would all Greek refugees be allowed to return to the island's north; this certainly made the proposal less

\footnotetext{
${ }^{54}$ Commission of the European Communities, Regelmäßiger Bericht 2001 der Kommission über Zyperns Fortschritte auf dem Weg zum Beitritt (Brussels, 2001), 25.

${ }^{55}$ William Wallace, "Reconciliation in Cyprus: The Window of Opportunity," Robert Schuman Centre Discussion Paper (Florence, 2002), 2.

${ }^{56}$ Reuter, "Zypern," 29-36.

${ }^{57}$ Pabst, "Zypern," 143.

${ }^{58}$ Commission, Regelmäßiger Bericht 2001, 22.
} 
attractive to the Greek Cypriot side, which has shown scant willingness to confront thorny issues from the past and make the necessary compromises on details of future nation building. ${ }^{59}$ Nonetheless, President Klirídis announced his willingness to find a compromise so as not to be responsible for the failure of new negotiations. In response, the Turkish side demanded the reestablishment of the confederation, because it did not agree with the stipulation in the accession talks that it speak with one voice in the EU. At the same time, the Turkish Cypriots were being asked to surrender partial sovereignty to the unified whole of Cyprus. Additionally, the occupation of Northern Cyprus was being called into question. A military presence under UN, NATO, or ESDP command, with mixed Greek and Turkish units, seemed more realistic to Annan, because Turkey could not afford any heightened security concerns, given its own EU membership prospects.

When Rauf Denktash offered to meet his former school friend Gláfkos Klirídis for the first time since 1997, the proposition took place with support from Ankara, in order to show a positive sign of Turkey's renewed willingness for negotiations before the European Council conference in Laeken, on 14-15 December 2001. Thus began a new marathon of talks in Nicosia between the UN representative de Soto and the two key persons who have rule the island's political machinations for decades. The new talks, as had become the pattern in the preceding years, were regarded by many observers as perhaps one of the last opportunities to solve the island's division before the accession of the Republic into the EU. ${ }^{60}$ Thus the urgency of the negotiations entailed a set schedule for the next six months (until the end of June 2002) to negotiate three times a week in the buffer zone with UN support, insulated from the public. In this manner, the Greek Cypriots and the EU, which pushed both sides to compromise, hoped to be able to include the criteria for a resolution to the conflict in the language of the accession treaty before the end of the accession negotiations. Otherwise the Union would be confronted with the unresolved Cyprus problem after enlargement, a complication that could threaten the EU's abilities to manage regional stability and security.

Although the more than forty bilateral meetings finally ended without concrete results, the conditions for a resolution to the conflict appeared more favorable than at any time since the founding of the Republic of Cyprus. The $\mathrm{EU}$, as a peace community, and its member states were to take a more active role in the Cyprus issue, in that they agreed to promote the readiness to compromise with appropriate financial as well as political-diplomatic incentives for both parties in the conflict. Otherwise, the entrance of a divided Cyprus into the

\footnotetext{
${ }^{59}$ For a possible alternative to the problem, see Neophytos G. Loizides and Marcos A. Antoniades, "A credible commitment model: Settler, refugee, and immigration issues in post-settlement Cyprus," Journal of Peace Research (forthcoming).

${ }^{60}$ Jürgen Reuter and Paris Varvaroussis, "Der Beitritt Zyperns zur Europäischen Union: Risiko für neue Instabilität der EU?” Südosteuropa-Mitteilungen 42:2 (2002): 66.
} 
EU would increase the likelihood of conflict on the island, as well as between Greece and Turkey. Consequently, this would endanger the security of the Eastern Mediterranean as well as the credibility of the EU Common Foreign and Security Policy. ${ }^{61}$ Up to this point, the EU Commission had sole responsibility for leading the accession negotiations with Cyprus and Turkey, because most member states had shown no strong inclination to get involved. In contrast to the case Macedonia, where representatives of the EU and the member states sent large amounts of money and prominent officials, the relative lack of interest and involvement in Cyprus is blatant, although the situation is just as unstable. ${ }^{62}$ Given previous experience, serious difficulties in finding a compromise are to be expected in the following areas:

- Binding constitutional agreements within the context of future Cypriot EU membership

- Return of (mainly Greek Cypriot) property and territorial changes (with the burden borne primarily by the Turkish Cypriots)

- The issue of the future of Turkish settlers in Northern Cyprus

- Credible security guarantees for the economic existence of the Turkish Cypriots

- Unity over transitional steps to build up mutual trust and to create support in both populations for the unavoidable adjustment process.

Despite these foreseeable difficulties, it is noteworthy that both sides were beginning as early as possible in the negotiations to eliminate their barriers to interethnic and economic contacts over the line of demarcation. The goal was to accomplish this even before the issues concerning status were resolved, and the EU promised to support such transitional steps with financial incentives.

Yet the danger of the unresolved Cyprus issue affecting the complicated internal EU decision-making processes remained, should a political solution not be reached at the last minute. In order to escape the dilemma of the selfmade Cyprus trap, the EU Commission tried to reduce the asymmetry in its Greek-Turkish-Cypriot relationship. At the same time, it has concentrated for a long time on convincing the Turkish Cypriots of the advantages to them of common EU membership with the Greek Cypriots: ${ }^{63}$

- The Turkish Cypriots would be free to determine their own internal structure and security measures after entrance into the Community. All existing accords with Turkey concerning the Cyprus solution would not be affected by the EU accession, so long as they do not prevent the

\footnotetext{
${ }^{61}$ Ludger Kühnhardt, "Stolperstein im Mittelmeer. Zypern vor dem Beitritt," Internationale Politik 57:1 (2002): 51. See George S. Yiangou, "The Accession of Cyprus to the EU: Challenges and Opportunities for the New European Regional Order," JEMIE 2 (2002).

${ }^{62}$ Wallace, Reconciliation, 7-12.

${ }^{63}$ Commission, Regelmäßiger Bericht 2001, 25 and Commission, 2002 regular report, 26.
} 
Cypriots from speaking with one voice in the EU committees and fulfilling their requirements as EU members.

- Since February 2002 the EU Commission has worked on a one-time only special adjustment program in the amount of over 206 million Euros (from 2004 until 2006) in support of the Turkish Cypriots, with the creation of a functioning market economy in the event of a prior settlement of the Cyprus dispute. In this case, the EU would offer further structural programs for modernization of agriculture and tourism in northern Cyprus - which would represent the poorest regions of the enlarged Union - in order to help alleviate fears of domination from the more economically successful Greek Cypriots. Furthermore, an EU informational centre in the Turkish Cypriot Chamber of Commerce is supposed to contribute efficiently to business people and EU politics as well as support the union movements in both parts of the island. As a result, the EU hopes to achieve improvements in relations between the ethnic groups and develop mutual interests before accession to the EU. Likewise, a communication strategy seeks to promote public awareness of and interest in the EU in both Cypriot communities.

- The EU referred to opinion polls in northern Cyprus, where more than 90 percent of the Turkish Cypriots recognize the economic and political advantages of EU membership and favor EU accession after the solution of the Cyprus issue. And it referred to left-wing nongovernmental organizations that are representing and organizing thousands of dissatisfied Turkish Cypriots who are in a state of unrest and are campaigning for a partnership state.

- The Community guaranteed to all Cypriots the primacy of democratic and human rights, including the protection of cultural, religious, and linguistic diversity. Democracy and the application of the rule of law were also secured, as well as inclusion of Greek and Turkish Cypriots in EU institutions.

- The EU also let the TRNC know that enlargement was their last chance to share in the wealth of the southern part of the island.

- In the end, the Commission has consistently worked since 1995 - partly in cooperation with the UN bi-communal projects, as well as with the program of confidence building measures - toward the construction of a strong civil society in both parts of Cyprus. ${ }^{64}$ At least a third of the 57 million Euros that the EU allocated to Cyprus for the accession preparations are therefore being used to finance reconciliation projects between the two ethnic groups.

\footnotetext{
${ }^{64} \mathrm{See}$, for instance, the contribution of the daughter of the former Greek Cypriot president and MP Katie Clerides, "Citizens as Peacemakers: The Experience of Cyprus," in Cyprus. In Search of Peace and Justice, eds. R. C. Sharma and Stavros A. Epaminondas (New Delhi, 1997), 248.
} 
Still, these activities have not been able to unfold between the populations of Cyprus, because the Turkish Cypriot leadership had long since created substantial impediments to the participation of people in any activities that involve crossing the demarcation line. Consequently, organizations, opposition parties, and unions led a demonstration in July 2001 under the slogan, "This Country is Ours!", in which about 3,000-4,000 Turkish Cypriots participated. The protesters contested the further economic degeneration of Turkish Cyprus and demanded that their government take a positive position toward the bi-communal activities. ${ }^{65}$ Furthermore, in summer 2002 some 86 NGOs, representing about 38,000 members, signed a declaration entitled the "Common Vision of the Turkish Cypriot Civil Society," ${ }^{66}$ calling for a mutual settlement of the Cyprus problem and full membership for Cyprus in the EU. The "Common Vision" does not favor two separate and sovereign states, but rather that the two politically equal sides should establish a "partnership state" with a single international legal identity and with an effective democratic process to manage its relations with the EU along the lines of the Annan proposals. ${ }^{67}$ Finally, the mass demonstrations in Lefkosa continued in 2002-03, even demanding Denktash's resignation. ${ }^{68}$ Indeed, the Union, and especially Germany, has been expected by both the negotiators and ethnic community leaders to consider the following basic demands for a successful conclusion of the present Greek-Turkish talks: ${ }^{69}$

- The political representatives from both parts of the island must finally recognize that one-sided suggestions will not lead to acceptable solutions for the unity, freedom, and prosperity of Cyprus. Therefore the two ethnic groups should permanently reject the option of annexation into their motherlands.

- Also, neither ethnic group can seek to dominate the other. The effective concept for the twenty-first century is the trusting cooperation of all Cypriots in a united Europe, in which the EU member states, as well as the regions and communities, have their own powers based on the principles of federalism and subsidiarity. Thus the EU member states, particularly those with high levels of ethnic diversity, should assure comprehensive societal and cultural rights of autonomy as an incentive for loyal participation in the central government as a way of preventing separatist tendencies.

- Similar to the Belgian case, ethnic groups should not be limited to their own settlement region; rather, a federal solution with two areas and two

\footnotetext{
${ }^{65}$ Commission, Regelmäßiger Bericht 2001, 10, 22.

${ }^{66}$ See the full text in http://www.dzforum.de (last access: 10 November 2003).

${ }^{67}$ Commission, 2002 regular report, 27.

${ }^{68}$ Axt, "Gordischer Knoten," 73.

${ }^{69}$ Athener Zeitung 5 April 2002, 22-24.
} 
communities should be reached. An enduring peaceful solution for Cyprus based on the bi-communal negotiations necessitates not only the mediation of the UN, but also the involvement of the Union as a believable regional guarantor of the stability of all of Cyprus.

When it became clear that the Turkish government had started to earnestly reform the constitution to fully comply with the Union's strict democratic criteria, and the religious-conservative Islamist (but Europhile) reformer Recep Tayyip Erdogan became prime minister in November 2002, Kofi Annan finally decided to present both Cypriot parties with his overall Basis for Agreement on a Comprehensive Settlement of the Cyprus Problem: "The status and relationship of the State of Cyprus, its 'common state' government, and its 'component states,' is modelled on the status and relationship of Switzerland, its federal government, and its Cantons." ${ }^{\prime 70}$ The "component states" are to secure the widest possible autonomy for both ethnic groups short of full sovereignty. Together with a rotating presidency, this model guarantees real political equality for Greek and Turkish Cypriots and enables Cyprus to speak with one voice as a state in the form of an "indissoluble partnership" resembling the constitution of 1959. All Cypriot citizens shall also enjoy internal component-state citizen status. As with European citizenship, this status shall complement and not replace Cypriot citizenship.

At the same time, Annan pushed for a separate referendum in both communities on his plan by the end of March 2003, essentially telling both parties that it was a "take it or leave it" proposition. In this way, he wanted to prevent new endless rounds of discussions with subsequent revisions, after his original plan had already been amended twice. ${ }^{71}$

The plan left room for diplomatic bargaining on only two major aspects of the Cyprus dispute: the problem of refugees whose homes were left behind enemy lines following the Turkish invasion, and the question of how the two communities would share Cyprus' territory. Notwithstanding their rhetoric, most Greek Cypriot politicians still have the following objections:

- With a Cyprus consisting of two sovereign "constituent states," the Turkish Cypriots could become so independent that they would gradually secede from the "United Cyprus Republic."

- The Annan plan establishes a divisive and dysfunctional system of governance that is inadequate for running an island like Cyprus.

- The plan essentially legitimizes the continued presence of the settlers from Turkey, and opens the way for the transformation of the demography of the island.

\footnotetext{
${ }^{70}$ See http://www.mfa.gov.tr, http://www.european-cyprus.net/cgibin/hweb?-A=612\&-V=eucy; and Axt "Gordischer Knoten," 68-71.

${ }^{71}$ See http://www.swp-berlin.org/produkte/brennpunkte/zypernchance1B.htm (last access: 17.12.2002; and http://www.pio.gov.cy/other/revised_un_plan.pdf.
} 
The Turkish Cypriot officials, on the other hand, are unhappy with the dominant position of the Greek Cypriots in the powerful central government institutions of the proposed federal state (the legislative and executive branches), a position which, to the UN, is simply a reflection of the numerical superiority of the Greek Cypriots. Regardless, it was argued that most legislation would emanate from the EU. Also, the plan does not grant the TRNC full recognition before they sign the plan. And, finally, whereas the Greeks demand full rights for refugees to return to their pre-1974 homes in northern Cyprus, including reoccupation, the Turks are only willing to offer compensation, because only a few Turkish Cypriots would want to live among Greek Cypriots again. ${ }^{72}$

In the final analysis, Annan failed again with his maneuver because, on 10 March Denktash, together with the Turkish government, finally rejected the third Annan Plan ${ }^{73}$ and the referendum, despite a more conciliatory reaction from the new reform government in Ankara to review its Cyprus policy. ${ }^{74}$ They now argued, instead, that the Annan plan did not serve Turkish interests. No doubt they had several good reasons for this decision: the then-ongoing Iraq crisis; the split in Europe over whether or not to ally with the U.S. and U.K.; the Turkish disappointment with the EU's decision to postpone the opening of membership negotiations until 2004; an internal dispute between Erdogan and the Turkish military on who has ultimate political authority; and, finally, the election of the new Greek Cypriot President Tássos Papadópoulos in February, with the support of the traditionally Cypriotist and moderate AKEL, because he was believed to be a traditional nationalist and "hard-line-rejectionist politician," due to his long EOKA past. ${ }^{75}$ Opinion polls taken at the time among Greek Cypriots also showed a negative attitude towards the Annan plan - in sharp contrast to the positive views expressed in Athens - because there is a widespread fear among Greek Cypriots that the Turkish Cypriot longing for political autonomy might reverse the traditional Greek majority over key decisions in territorial and property questions. ${ }^{76}$

But it was the Turkish refusal that put an indefinite hold on the Annan plan, the most intense efforts of the UN to solve the Cyprus problem on the basis of a detailed plan for a comprehensive settlement. In mid-April 2003, it was President Papadópoulos alone who signed the accession treaties with the EU in Athens in a ceremonial act under the Greek EU Presidency. Only a week later, deputy Prime Minister Serdar Denktash, son of the President, officially

72 "Cyprus-Question. Recent developments on Cyprus," Foundation Center for Studies on Turkey (FRAME), 20 April 2003, at (http://www.zft-online.de/news/article/detail.php?ds= 090ff54ae1afbd8427af91917d2fe173, last access: 10 November 2003).

${ }_{73}$ See http://www.typos.com.cy/nqcontent.cfm?a id=28596 (last access: 10 November 2003).

${ }^{74}$ Paris Varvaroussis, "Der Beitritt Zyperns zur Europäischen Union und die Sicherheit in der Region," Südosteuropa Mitteilungen 43:3 (2003): 63, footnote 13.

${ }^{75}$ Caesar V. Mavratsas, "Aspects of the Cyprus Problem: Political and Culture and Civil Society," Culture in Common, 38.

${ }^{76}$ Axt "Gordischer Knoten," 76. 
opened the internal "borders" of Northern Cyprus for visitors from both communities, commenting in the press that, "Cypriots can perhaps begin solving the Cyprus problem on their own, without outside interference - and they should do it gradually." ${ }^{\prime 77}$ It seems that this shocking move to partially lift restrictions on free movement on the island was mainly intended to channel the ever-rising amount of internal frustration against the Denktash regime. But, as with the fall of the Berlin Wall in 1989, thousands of ordinary Greek and Turkish Cypriots were at least initially euphoric at crossing the Green Line that had separated the island since 1963. This sudden and dramatic change transformed the Cyprus problem, with an effect whose outcome is still unknown: the experiment will have to prove whether the civil societies are ahead of the politicians, and whether the Cyprus problem can now be solved "from the bottom up." If so, it might lead to a decisive rapprochement between both communities in the long run.

The parliamentary elections in Northern Cyprus in December 2003 will test whether the anti-Denktash opposition, with the support of the EU, is already decisive enough to convince a majority of voters that the president of the TRNC must no longer be automatically viewed as the spokesman for his community in the next inter-communal negotiations. And, for the first time ever, the EU Commission in its latest progress report (November 2003) on Turkey's accession, while still avoiding taking over any direct mediation in resolving the Cyprus problem, put unusually direct political pressure on Turkey to finally push the Turkish Cypriot government to resume negotiation talks on the basis of the Annan plan. Otherwise, it openly threatened that, "the absence of a settlement could become a serious obstacle to Turkey's EU aspirations." At the same time, it offered its assistance to find a "speedy solution to the Cyprus problem."'78

The message the EU sent to Turkey is clear: there is a link between the settlement of the Cyprus dispute and Turkish EU membership. When the Greek part of Cyprus has become an EU member as the Republic of Cyprus, Turkey will, after May 2004, be meeting at the negotiating table a country which Ankara does not officially recognize. Moreover, Turkey will be in the position of being an occupation force in EU territory. This is why a solution to the problem is so important in realizing Turkish membership in the EU. However, Turkey needs to feel that the EU is serious about Turkey's membership; only then may it be willing to make compromises to solve the problem on the basis of the Annan plan, which has failed to meet the expectations of nationalists on both sides.

\section{Integration of Cyprus in the EU: An Effective Model Resolving Diverging Ethnic Interests?}

Cyprus signifies a special case in the forthcoming round of EU enlargement, given its distinctive insular geography between Christian occident and Muslim

\footnotetext{
${ }^{77}$ Mavratsas, "Aspects," 38.

${ }^{78}$ EU Commission, Continuing Enlargement, 5, 20.
} 
orient as well as its apparently insurmountable international and historical problems of domestic co-existence involving two different ethnic groups with different ethno-religious identities. In view of that, the island offers a unique "window of opportunity," in Kofi Annan's words, to try out new models of conflict resolution. For the EU, a promotional role as stability provider, peacemaker, and prosperity benefactor in the Eastern Mediterranean could develop, if the EU succeeds at applying the dynamics of enlargement as a strategic instrument of flexible cooperation in the service of overcoming the diplomatic stalemate in the island's ongoing conflict.

But applying "democratic conditionality" 79 as the most frequently evoked feature of the enlargement process led to an asymmetrical impact: the Community, under pressure from its member state, Greece, permitted only the Greek Cypriots to enter the EU as the sole representatives of the unified government of the already deceased Republic of Cyprus. Thus the Union lost its own impartiality in the dispute, to the advantage of the Greek side. Then the EU started an exclusive material bargaining process with the Turkish Cypriots, offering attractive financial incentives to accept the conditions of the Annan plan and join the Greek-dominated negotiation team in Brussels in a minority status, while keeping Turkey on the waiting list for membership, during which time her commitment to democratic norms and values, as well as to resolving the Cyprus dispute, come under intense scrutiny. The EU's credibility as a political actor has suffered a great deal, as did the political representatives in both communities with their ambivalent responses to the Annan plan. If both parts do not succeed by May 2004 to officially join the EU together, they will have to pay the price: "The Greeks will not receive any of the occupied lands back, and the Turks will continue in their political isolation and economic misery." $" 80$

However, the necessary rapprochement of the deeply divided conflicting parties in Cyprus requires an approach to problem-solving beyond the rubric of the nation-state. Meanwhile, the EU is experimenting with new forms of governance in the European multi-level system. ${ }^{81}$ This European governance is ideally based on a complex, balanced dialogue led by the governments, the EU institutions, and the civil society in Europe, and at the same time interested in a collective, binding arbitration and decision system. If the EU manages to transfer the success of its governance approach to the solution of the Cyprus problem, then it could promote more flexibility, willingness to cooperate, and acceptance among the conflicting parties for an end to the island's security dilemma and division. As an educational community, the EU can act as an

${ }^{79}$ See Frank Schimmelfennig, Stefan Engert, and Heiko Knobel, "Costs, Commitment, and Compliance. The impact of EU democratic conditionality on Latvia, Slovakia, and Turkey," Journal of Common Market Studies 41:3 (2003): 495-517.

${ }^{80}$ Mavratsas, "Aspects," 39.

${ }^{81}$ See Commission of the European Communities, European Governance. A White Paper (Luxembourg, 2001). 
example for the political elites of divided Cyprus, and illustrate how radically relations in the multi-level system have changed as a result of European integration. It follows that the classical terms of nation-state, sovereignty, and statehood have lost their everyday political significance. In addition, one needs to consider the large variety of political and constitutional systems within the EU, which reach from the relatively centralized models of France and United Kingdom to the loose federal structure of Belgium. Therefore, it is not too difficult for the Community to offer plausible assurances of protection to the Turkish Cypriot group within its limited territory. ${ }^{82}$

In coming to grips with the Cyprus issue, the EU must further develop practical measures in the near future, to prevent the small island of Aphrodite from becoming the largest problem of EU enlargement. Simultaneously, an increase in stability will result only if the EU manages to define its relations to Turkey more clearly. Yet it may prove quite helpful that Cyprus is the first accession country that must bring together on the national level two opposing cultures, drawing on Christian and Muslim traditions. The EU should show that the accession of Cyprus cannot be perceived as a victory for the Greek Cypriot population over the Turkish Cypriot minority; rather, the entire population of Cyprus benefits. Thus, it must be examined, whether - after the freedom to travel has been improved below the threshold of an international acknowledgement of Northern Cyprus - compulsory resettlements can be excluded, and the TRNC can participate in the free trade and customs union. Additionally, as with the codification of the Turkish language as an official EU language in the accession treaty, the Republic of Cyprus must be persuaded to make a constructive contribution. ${ }^{83}$ The future of the Community depends considerably on whether the EU succeeds at establishing a broad democratic dialogue between the traditional Christian and Islamic archrivals within a shared Western and secular political framework.$^{84}$ Here, the EU will have to involve itself more intensively than it has previously done in the cooperation between both groups on Cyprus in order to demonstrate its integrity and credibility to these new European citizens. Ultimately, whether Cypriots of both ethnic groups will be able to solve their conflicts amiably with EU support under the common umbrella of Europe ultimately will depend on the number and extent of bi-communal networks that are created. In this manner, Turks and Greeks in Cyprus must first learn that they can realize their interests believably, profitably, and efficiently only through joint membership in an enlarged European Community.

“Wandel durch Annäherung” (transformation by mutual approach), to cite Egon Bahr, the architect of the inner German détente policy in the 1970s, can only be realized within Cyprus if the two parties move closer together from

\footnotetext{
${ }^{82}$ Wallace, Reconciliation, 9.

${ }^{83}$ Deutsch-Zyprisches Bürgerforum. Projektbericht (Köln, 2001), 11-19.

${ }^{84}$ Larry Siedentop, Democracy in Europe (London, 2000), 207.
} 
project to project under the stable framework of the EU, guaranteeing to NGO's the freedom to conduct inter-communal activities, creating mutual trust and understanding for interethnic cooperation. Then both camps will have to accept that the two existing political systems in one country ${ }^{85}$ can in fact peacefully coexist to their mutual benefit under a loose state federation and, with Greece and Turkey closely integrated in the European Union, contribute finally to peace and stability in the Eastern Mediterranean. Thus the real strength of the EU to solve the Cyprus problem lies in its "power of attraction." ${ }^{86}$ Eventual full EU membership for Cyprus and Turkey offers the necessary incentives and the economic, political, legal, and security frameworks to accommodate the integration after the settlement of the Cyprus dispute. But it will largely depend on the political interests of all domestic and external parties involved to provide for rapprochement as the condition for trustworthy and binding commitments to finally regulate inter-communal co-existence on the basis of the Annan plan.

${ }^{85}$ Zervakis, "Die politischen Systeme Zyperns," 889; and H. Tarik Oguzlu, "The EU as an actor in the solution of the Cyprus dispute: The question of "how'," JEMIE 2 (2002): 21.

${ }^{86}$ George Christou, "The European Union and Cyprus: The power of attraction as a solution to the Cyprus issue," JEMIE 2 (2002): 22. 


\section{Bibliography}

Brewin, Christopher. The European Union and Cyprus. Huntingdon, 2000.

Diez, Thomas. "Why the EU can nonetheless be good for Cyprus." Journal of Ethnopolitics and Minority Issues in Europe (JEMIE) (2002).

Reiterer, Albert F.. Cyprus. Case study about a failure of ethno-national understanding . Frankfurt am Main, 2003.

Sbragia, Alberta M.. "Thinking about the European Future: The Uses of Comparison." Washington, D.C, 1992.

Zervakis, Peter. "Die politischen Systeme Zyperns." In Die politischen Systeme Osteuropas. Opladen, 2002. 


\section{Bibliography}

Brewin, Christopher. The European Union and Cyprus. Huntingdon, 2000.

Diez, Thomas. "Why the EU can nonetheless be good for Cyprus." Journal of Ethnopolitics and Minority Issues in Europe (JEMIE) (2002).

Reiterer, Albert F.. Cyprus. Case study about a failure of ethno-national understanding . Frankfurt am Main, 2003.

Sbragia, Alberta M.. "Thinking about the European Future: The Uses of Comparison." Washington, D.C, 1992.

Zervakis, Peter. "Die politischen Systeme Zyperns." In Die politischen Systeme Osteuropas. Opladen, 2002. 